\title{
CrimRxiv
}

\section{The Prison of Democracy: Race, Leavenworth, and the Culture of Law}

Sara M. Benson

Published on: Mar 04, 2022

DOI: $10.21428 / \mathrm{cb} 6 \mathrm{ab} 371.8 \mathrm{f} 7 \mathrm{becd} 6$

License: Creative Commons Attribution 4.0 International License (CC-BY 4.0). 
